ISSN 2449-7479

eISSN 2543-8840

amme.wne.sggw.pl

Annals of Marketing Management \& Economics

Vol. 4, No 1, 2018, 73-87

DOI 10.22630/AMME.2018.4.1.6

\title{
DEVELOPMENT OF SOCIAL CAPITAL BY STRENGTHENING OF DIGITAL COMPETENCES AMONG GROUPS EXPOSED TO SOCIAL EXCLUSION
}

\author{
Paweł Pięta \\ Warsaw University of Life Sciences - SGGW, Poland
}

\section{INTRODUCTION}

In the modern world, competitive advantage on the professional market is shaped by competences known as skills, qualifications, and permissions. The number of typologies can be found in the subject literature. One of the classifications distinguished two types of competences: soft and functional (or otherwise known as specializing, hard and technical) [Moczydłowska 2008]. Within the specialized competences, IT skills can be distinguished. They are referred to as digital competences. They were recognized as key competences by the European Parliament and the council of the European Union. These define a set of rudiments, knowledge and foundation skills necessary for the active and purposeful participation of a person in social life. The lack or low level of digital competences is particular evident among groups which are at risk of exclusion primary among elderly people, people living in rural areas and those with a low level of education. In relation to these groups, various types of activities are carried out to reduce disparities in these areas, which leads to increase the involvement of these people in the development of their competences which undoubtedly affects social development of these groups and society as a whole. One of those activities was the Digital Poland Equal Opportunities (PCRS) project, the aim of which was to introduce the world of digital communication as well as service and content available on the Internet - polish adult generation 50+. This was implemented by the association "City on the Internet" and Ministry of Administration and Digitalisation. The project based on volunteers work who was referred to as the lamplotters. They played the role of a modern social animator. One of the lamplotters was the author of an article, who carried out two projects. They were addressed to people aged $50+$ from the Łowicki county (Łódź Voivodeship) and those living in rural areas, in to the group of people most exposed to digital exclusion. 
In total, over 700 people took part in both projects, and among this group of people survey research was carried out. On the one hand, these researchers were aimed at getting to know the opinions of the training participants about the activities carried out, and on the other hand, assessing the acquired knowledge in the context of their usefulness in both social and professional life. Research and conclusions are presented in the article.

\section{KEY COMPETENCES - THE MOST IMPORTANT INFORMATION}

The starting point for considerations is the development of social capital among groups that are exposed to social exclusion and the presentation of basic and most important information related to key competences and their definition. This concept in the literature of the subject is quite well-known. It was sanctioned by the European Union in 2006. On 18 December 2006, the European Parliament and the Council of the European Union adopted recommendations on key competences for lifelong learning [Zalecenie Parlamentu...]. With regard to the subject of development, these recommendations are valid for three reasons. Firstly, it was stressed that in the face of globalization and the transition to a knowledge-based economy model, a framework is needed that will identify new skills acquired through lifelong learning. Secondly, it was noted that the learning process covers the period from pre-school age to retirement age. Thirdly, it was also pointed out that all activities related to this process must be aimed primarily at the unemployed and inactive people for various reasons, which underlined the status of socially excluded groups in which various types of activities should be intensified. These activities are aimed at the implementation of the assumptions referred to, in the recommendations on key competences in the process of lifelong learning [Maniak 2015].

The European Union has identified key competences as a set of rudiments, skills, and foundations that are necessary from the point of view of purposeful and active participation of a given person in social life. In connection with this definition, eight key competences have been established [Zalecenie Parlamentu...]:

- communicating in the mother tongue;

- communicating in foreign languages;

- mathematical competences and basic scientific and technical competences;

- IT competences;

- ability to learn;

- social and civil competences;

- initiative and entrepreneurship;

- cultural awareness and expression.

In accordance with the recommendations of the European Parliament and the Council of the European Union, activities implemented as part of the lifelong learning process must be implemented in such a way that participants of these activities can acquire knowledge and skills related to key competences. Attention should be paid to the education and training of young people who, thanks to this, acquire knowledge constituting the basis for further education so necessary in both private and professional life. It is also important to educate adults who, despite their knowledge, have the opportunity to develop and update their key competences. This education is important in relation to people who have certain deficits and are exposed to social exclusion [Górniak 2014]. 
At this point, it is also worth defining the very concept of social exclusion. According to one of many definitions, the term describes a situation in which a given person belonging to a given society cannot fully participate in activities carried out by other representatives of that society [Nowak 2012]. The exclusion of a given individual may manifest itself in various areas of life, including in economic, political or cultural life. People exposed to such activities are people who do not have access to resources, goods or institutions, or this access is limited. One of the examples of exclusion is digital exclusion, which is related to the situation in which the persons do not have the opportunity to use modern information and communication technologies in their lives, both private and professional. In order to implement the process of lifelong learning by individual institutions or entities, infrastructure plays an important role, understood not only as access to lecture halls or training rooms but also as access to teachers and trainers [Dach 2008]. Lack or limited access to lecture halls or teachers can also lead to digital exclusion. In the literature of the subject, digital exclusion is often referred to as the digital abyss. These two terms are used interchangeably to identify differences between people and societies that have access to information technologies and those who do not. The ever more dynamic development of information technologies leads to increasing differences between the two groups. Undoubtedly one of the most important causes of the "digital abyss" is the lack of adequate internet infrastructure, which does not facilitate access and does not allow the use of communication and information technologies. It should also be emphasized that digital exclusion is not only a lack of access to appropriate infrastructure but also a lack of skills in using a computer and the Internet [Popiołek 2013].

\section{DIGITAL COMPETENCES, AREAS OF DIGITAL SKILLS}

The eight key competences established by the European Union are considered equally important, mainly due to the fact that they are not only complementary but also partly overlap. For the needs of the study, IT competences will be discussed, which currently include a larger thematic range and are referred to as digital skills. In the recommendations of the European Parliament and the European Union, they have been defined as those whose possession gives the opportunity to skillfully and critically use of digital technologies in professional life, recreation, and daily communication. IT competences are nothing more than the use of computers that are used to obtain information, evaluate and store, create, present and exchange information. They are also used for communication and participation, which is carried out via the Internet. On the one hand, people with such skills must be able to handle computer applications, but on the other hand, they must demonstrate creativity and innovation. The development of the above-mentioned skills contributes to the development of social capital through the interest in participating in a given social group, which serves to satisfy cultural, social or professional needs [Zalecenie Parlamentu...].

The available subject literature has a number of terms that are referred to as IT competences, including primarily digital competences and e-competences [Warszawski Instytut... 2015]. Digital skills give the opportunity to effectively use digital technologies in various areas of life. Digital technologies are not only a computer that has access to the 
Internet but also mobile technologies and devices, such as ticket machines or automated parcel lockers.

Digital competences (or e-skills) contain a number of skills that can be distinguished, separately presented and characterized. There are many different typologies in the available studies. The very concept of "digital competences" is used in European Union documents, and behind them are developed documents, reports, analyzes, and programs prepared by the governments of member countries. The European Union distinguishes digital skills, within five groups can be distinguished, i.e. [Gareis et al. 2014]:

- information (browsing, searching, filtering of received information, evaluation of information and storage of information);

- communication (social interactions that are implemented using modern technology, information sharing, citizen participation on the Internet, identity management and online cooperation);

- creating content (creation of content and combining them, processing, copyright/licences, and programming);

- safety (protection of devices used by a given person, security of data/digital identity and protection of health and the environment);

- problem solving (solving technical problems, identifying needs and their solutions, innovativeness, creativity, defining gaps that occur within digital competences).

In the literature of the subject, there is a whole range of different catalogs, which often specify very detailed IT skills or broadly understood digital competences. Most of these definitions are based on documents developed by the European Parliament and the Council of the European Union.

\section{GROUPS EXPOSED TO DIGITAL EXCLUSION - STATISTICAL DATA}

The percentage of people with Internet access in the European Union is high, although there are significant differences between the countries. Among the 28 countries belonging to the European Union, the percentage of households with Internet access reached $85.0 \%$ in 2016 (compared to $55.0 \%$ in 2007). In 2016, the highest percentage $(97.0 \%)$ was recorded in Luxembourg and the Netherlands. Among the EU Member States, the lowest percentage of households with Internet access was recorded in Bulgaria (64.0\%). According to Eurostat data, this percentage in Poland was $80.0 \%$ [EUROSTAT 2017].

The various surveys carried out over decades have shown that the percentage of Poles who use modern information and communication technologies in their lives increases year by year. This is also confirmed by the data of the Central Statistical Office. However, it should be noted that the impact on the percentage of people using the Internet depends on the level of education, place of residence or wealth [Tomaszewska 2013, Local Data Bank...].

Over the past 10 years, the number of households having a computer increased from $33.7 \%$ in 2003 to $72.1 \%$ of households in 2015 . However, it should be noted that in 2003 this percentage was $16.9 \%$, while in 2015 this percentage remained at a similar level to that of households with a computer. Interesting is also the fact that with the increase in 
the number of households having a computer and access to the Internet, the percentage of households with a landline telephone decreased. Changes in this area in Polish households have been presented in the chart below (Fig. 1).

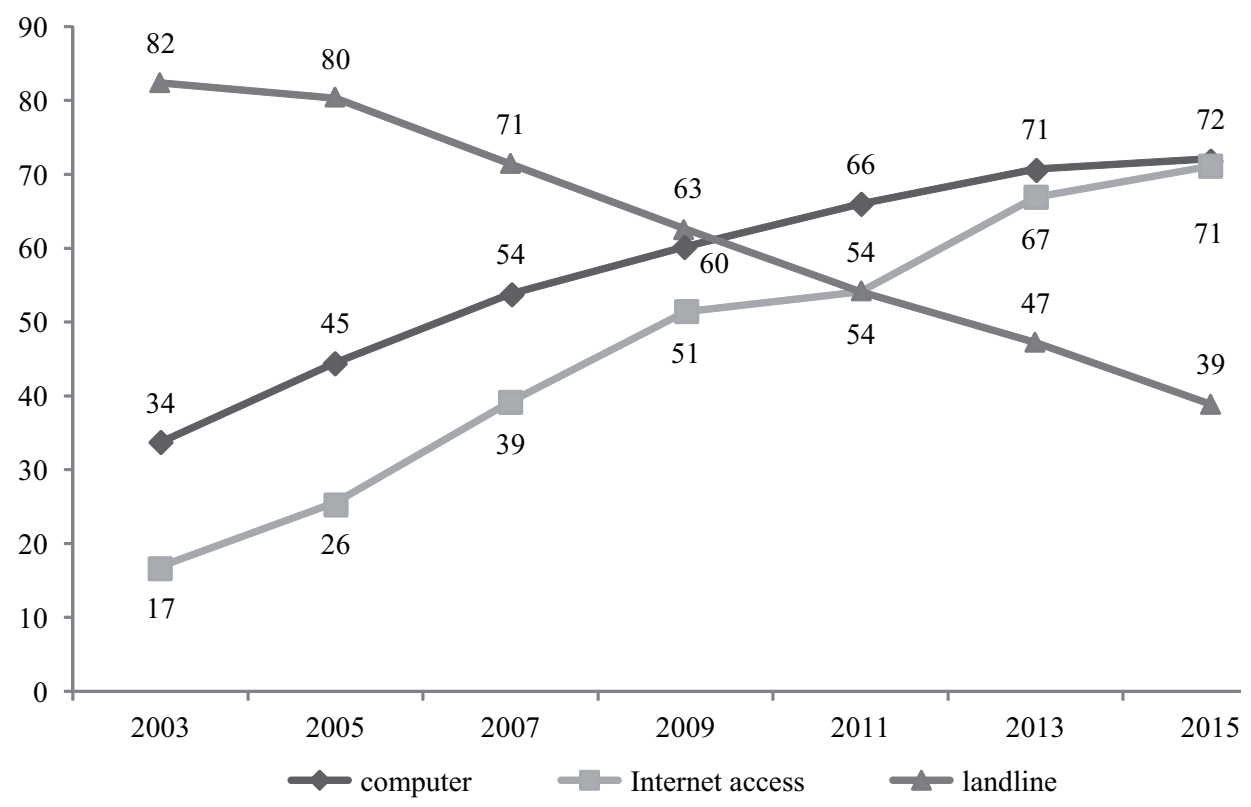

FIG. 1. Household equipment with a computer, Internet access and landline telephone in 2003$-2015[\%]$

Source: [Batorski 2015].

The statistical Polish citizen is increasingly using mobile Internet and mobile devices such as a tablet or a smartphone. Research shows that every fourth household has at least one laptop. As a result, the number of households with a desktop computer is decreasing. As it was already mentioned before, the presence of computers or access to the Internet depends also on the size of the place of residence or income per person in a given household. These data are presented in the scale below (Table 1).

The data presented above shows that the most deprived persons of the digital exclusion are the poorest, i.e. those in which the income per person in the household does not exceed the first quartile. However, it should be noted, that among this group, the percentage of households that have access to the Internet was growing the fastest within a few years (from $19.1 \%$ in 2007 to $54.5 \%$ in 2015). In households which the income exceeded the third quartile had Internet access in more than $90.0 \%$ of cases. In addition to the income that affects the accessibility to modern technologies, the place of residence plays an important role. For people in cities over 500,000 inhabitants in 2015, 82.3\% of households had access to the Internet, while in the case of a village this percentage was maintained at about $67.5 \%$. 
TABLE 1. Availability of the Internet in various types of households in 2007-2015 [\%]

\begin{tabular}{|c|c|c|c|c|c|c|}
\hline \multirow{3}{*}{\multicolumn{2}{|c|}{ Group of households }} & \multicolumn{3}{|c|}{ Internet } & Computer & Tablet \\
\hline & & \multicolumn{5}{|c|}{ Years } \\
\hline & & 2007 & 2011 & 2015 & 2015 & 2015 \\
\hline \multirow{6}{*}{$\begin{array}{l}\text { Size of the } \\
\text { residence place }\end{array}$} & citiesover 500,000 & 57.6 & 73.3 & 82.3 & 81.7 & 32.0 \\
\hline & cities $200,000-500,000$ & 50.2 & 68.7 & 76.1 & 75.9 & 29.7 \\
\hline & cities $100,000-200,000$ & 44.3 & 64.6 & 76.3 & 76.6 & 25.8 \\
\hline & cities $20,000-100,000$ & 44.2 & 62.0 & 69.2 & 69.0 & 22.6 \\
\hline & citiesbelow 20,000 & 40.2 & 61.4 & 69.9 & 70.1 & 22.2 \\
\hline & village & 22.4 & 51.7 & 67.5 & 68.3 & 20.2 \\
\hline \multirow{4}{*}{$\begin{array}{l}\text { Income per person } \\
\text { in households }\end{array}$} & to the firstquarter & 19.1 & 41.1 & 54.5 & 54.9 & 15.0 \\
\hline & from the first to the secondquartile & 30.7 & 54.1 & 61.4 & 61.4 & 17.2 \\
\hline & from the second to the third quartile & 41.7 & 62.3 & 77.5 & 77.4 & 25.7 \\
\hline & above the third quartile & 60.1 & 83.3 & 90.5 & 90.8 & 36.0 \\
\hline
\end{tabular}

Source: [Batorski 2015].

The use of modern technologies is becoming more and more common. However, there are some differences in the use of these technologies among various social or professional groups. These differences are also visible in terms of age, social-professional status and education. These factors, as the data show, affect the percentage of people using computers or other devices with access to the Internet, and thus indicate groups of people who statistically more often than others are exposed to digital exclusion (Table 2).

In everyday life, modern technologies are used more and more often for shopping. Electronic commerce or so-called e-commerce is a dynamically growing sector of trade. Its importance in the global economy is systematically growing [Grochal-Brejdak 2016]. In Poland, shopping on the Internet is more often carried out by women than men. This percentage has not changed over two years. Most often, people 35 years up to 49 years of age decide to shop online. People over 50 years of age do their shopping online the least. People with secondary education more often than people with a different level of education decide to shop online. It is interesting to note that the percentage of people shopping online with low education decreased over the last two years. In the case of a place of residence, it can be noticed that the residents of villages decide to shop online the least often. Interestingly, in the last two years, the percentage of rural residents active in the e-commerce market has decreased. Most often, residents of cities under 200,000 are active on the electronic market. The selected demographics of buyers online are presented below (Table 3).

The data presented above shows that the percentage of people using a computer or the Internet is decreasing with age. Only one in five people over 65 years of age use modern technologies. It is the elderly who are most often mentioned in the group of people exposed to digital exclusion. Most often modern information and communication technologies are used by young people up to 34 years of age. The socio-professional status also affects the percentage of people using modern technologies. The available data show that the lowest percentage of people using modern technologies is recorded among pensioners 
TABLE 2. Using the computer and the Internet in various groups in 2015 [\%]

\begin{tabular}{|c|c|c|c|}
\hline \multicolumn{2}{|c|}{ Groups } & Computer & Internet \\
\hline \multirow{6}{*}{ Age } & $16-24$ years & 97.2 & 97.5 \\
\hline & $25-34$ years & 92.5 & 92.9 \\
\hline & $35-44$ years & 85.2 & 85.6 \\
\hline & $45-59$ years & 60.3 & 60.0 \\
\hline & $60-64$ years & 41.3 & 40.8 \\
\hline & 65 years and older & 18.6 & 17.9 \\
\hline \multirow{9}{*}{ Professional and social status } & public sectorwork & 89.4 & 89.4 \\
\hline & work of the privatesector & 82.4 & 83.1 \\
\hline & privateentrepreneurs & 90.2 & 89.6 \\
\hline & farmers & 51.0 & 50.5 \\
\hline & pensioners & 32.9 & 32.6 \\
\hline & retirees & 25.9 & 25.2 \\
\hline & pupils and students & 98.8 & 98.8 \\
\hline & unemployed & 68.4 & 68.9 \\
\hline & othersprofessionallyinactive & 63.2 & 63.2 \\
\hline \multirow{5}{*}{ Education } & elementary and lowereducation & 15.1 & 14.7 \\
\hline & basic and post-secondaryeducation & 49.0 & 49.4 \\
\hline & secondaryeducation & 74.1 & 73.8 \\
\hline & higher and post-secondaryeducation & 92.3 & 92.3 \\
\hline & learner & 98.8 & 98.8 \\
\hline
\end{tabular}

* A larger percentage of people using the Internet than a computer shows that, above all, they have access to a computer through mobile devices, such as a mobile phone, smartphone or tablet.

Source: [Batorski 2015].

TABLE 3. Selected demographic data of people buying on the Internet for 2015-2017 [\%]

\begin{tabular}{|c|c|c|c|}
\hline \multirow{2}{*}{ Gender } & Specification & 2015 & 2017 \\
\cline { 2 - 4 } & women & 53 & 53 \\
\hline \multirow{3}{*}{ Age } & men & 47 & 47 \\
\cline { 2 - 4 } & $15-24$ & 26 & 29 \\
\cline { 2 - 4 } & $25-34$ & 34 & 29 \\
\cline { 2 - 4 } & $35-49$ & 28 & 30 \\
\hline \multirow{3}{*}{$\begin{array}{c}\text { Education } \\
\text { The size of the place of } \\
\text { residence }\end{array}$} & lowereducation & 12 & 13 \\
\cline { 2 - 4 } & secondaryeducator & 24 & 22 \\
\cline { 2 - 4 } & highereducation & 34 & 47 \\
\cline { 2 - 4 } & cityup to 200,000 residents & 29 & 30 \\
\hline \multirow{3}{*}{$\begin{array}{c}\text { cillage } \\
\text { cityabove 200,000 residents }\end{array}$} & 32 & 44 \\
\hline
\end{tabular}

Source: the author based on Gemius 2015, 2017. 
and the highest among learners and economically active (both private and public sector employees). Only every second farmer uses a computer and the Internet. People with low education are also exposed to digital exclusion. Along with the increase in the level of education, the percentage of people using modern technologies in both private and professional life increases.

\section{ACTIVITIES AIMED AT THE DEVELOPMENT OF DIGITAL COMPETENCES AMONG GROUPS VULNERABLE TO SOCIAL EXCLUSION}

Data presented in the study show that among the groups exposed to social exclusion due to the lack of digital skills or having a low level of digital skills are older people, coming from poorer families, low level of education and people living in rural areas and small towns. It was in relation to these groups over the years that activities aimed at developing their digital competences were implemented. One of such actions was the Digital Poland Equal Opportunities (PCRS) project. The originators of this undertaking directed their activities towards people over 50 years of age. PCRS is a grassroots initiative. Its goal was to introduce digital communication, services, and content available on the Internet - adult Poles from the $50+$ generation. The project was implemented by the Association "City on the Internet" and the Ministry of Administration and Digitization. It was based on the work of lamplotters - volunteers who acted as a modern social animator. The project was carried out from November 2011 to the end of 2015. Activities focused on identifying and training more than 2,600 people who became the main beneficiaries of the project. They were usually local leaders, digital education enthusiasts, trusting people in their local communities. From such a large number of people, the institution implementing the project chose more than 250 people who received grants for the implementation of their Local Digital Education Plans. In whole Poland, over 37,000 classes were carried out, in which almost 280,000 people age 50+ attended. These classes lasted almost 73,000 hours. In addition to the implementation of activities with people 50+, the project also provided regular meetings and training of lamplotters in various parts of Poland, as well as conventions from the National Polish Association of Lamplotters [Szymańska-Palaczyk 2016, WWW1].

\section{RESULTS AND ANALYSIS OF THE CONDUCTED RESEARCH}

As part of the Digital Poland of Equal Opportunities project, the author of the article has realized two projects: "Łowiccy seniorzy XXI wieku" (Lowicz seniors of the 21st century [in Polish]) (lasting from 01.01.2013-30.06.2014) and "Księżacy on-line" (lasting from 01.10.2014-30.06.2015). Both projects were directed to people aged 50+ from the Łowicki county (Łódź Voivodeship) and those living in rural areas, ie to the group of people most exposed to exclusion. The classes were carried out in buildings belonging to the volunteer fire brigade, in communal libraries, in computer labs of rural schools and village centers. Over 700 people took part in both projects. The average workshop cycle for a given group ranged from five to six two-hour meetings. 
During the course of the classes, a survey was carried out using the questionnaire. One hundred participants of the course took part in it, half of them were pensioners, followed by working people (38\%) and unemployed (12\%). The main goal of the conducted research was to get to know the opinions of participants of computer workshops about the organized training, the person running them and the usefulness of the training. Among the people who participated in the study, the following groups of participants can be distinguished:

- had a computer with Internet access $-73 \%$ of respondents;

- they did not have a computer, but after the training, they planned to invest in its purchase and connect to the Internet $-18 \%$ of the respondents;

- had a computer that was not connected to the Internet - $9 \%$ of respondents.

The information provided shows that most of the participants had a computer that was connected to the Internet. Despite this, they did not have the knowledge and skills to use it. According to the participants of the training, participation in it was to encourage, and above all, eliminate barriers that did not allow people over 50 to use the computer and the Internet. The persons who took part in the survey also evaluated the organization of training, in particular, the conditions enabling the integration, a suitably planned dimension of time, the quality of equipment used during the classes, the place where the training was held and the relevant notice of the date and place of the meeting. The distribution of answers to the questions in the survey is presented below (see Fig. 2).

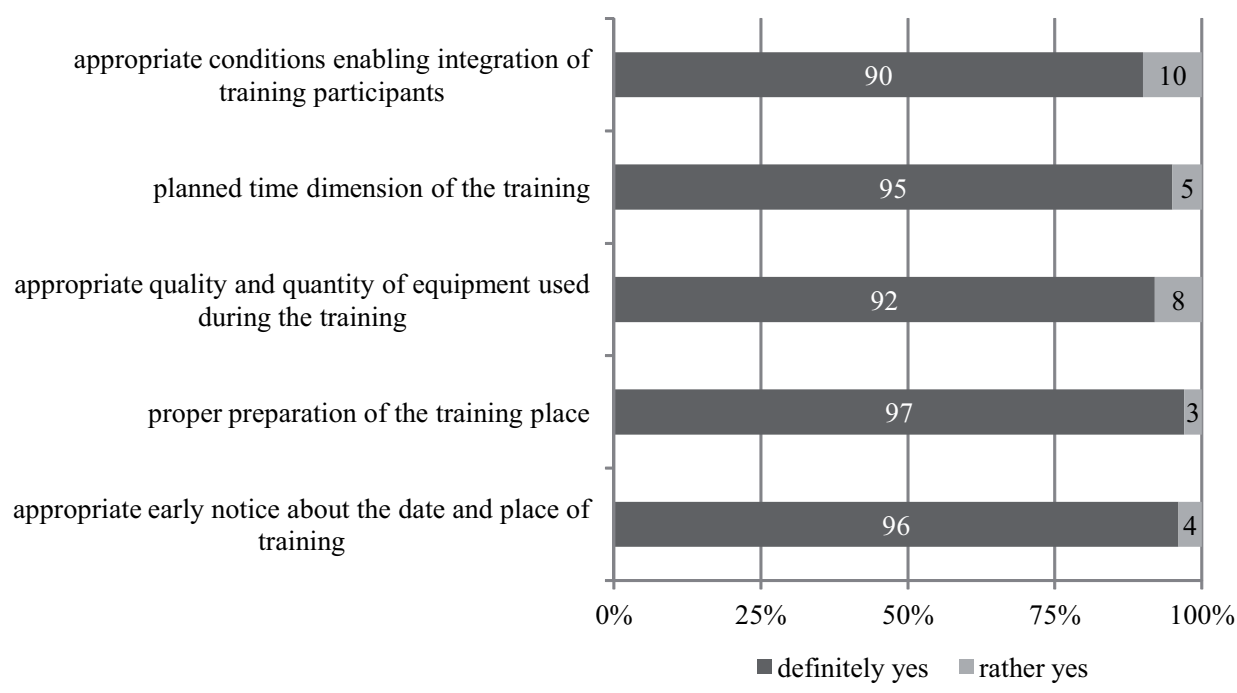

FIG. 2. Distribution of answers to questions regarding the evaluation of training organization [\%] Source: the author's research.

The respondents assessed the organization of training in which they participated very well. The time dimension according to the people who took part in the survey was rated as: 
- just right $-43 \%$;

- rather too short $-40 \%$;

- far too short $-15 \%$;

- too short $-2 \%$.

In addition to the evaluation of the training organization, the persons participating in the study gave an opinion on the person conducting the training. The respondents were asked about the atmosphere prevailing during the training, commitment and substantive preparation of the person running them. The distribution of answers to questions asked in the survey is presented below (Fig. 3).

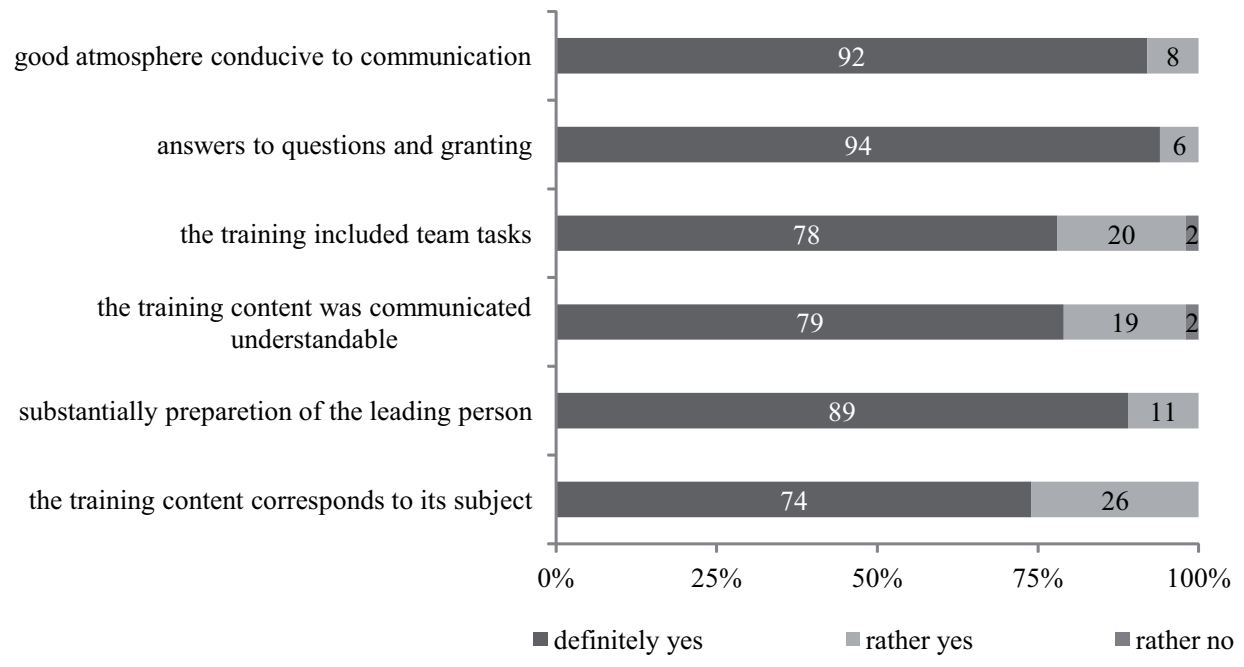

FIG. 3. The distribution of answers to questions about the evaluation of the person conducting the training [\%]

Source: the author's research.

The respondents also answered questions related to the assessment of the usefulness of training. The vast majority of people were satisfied with the training ( $81 \%$ of the respondents indicated the answer definitely yes, $13 \%$ of respondents - rather yes, $6 \%$ of the respondents indicated the answer "rather not"). Respondents were asked to answer questions related to whether they would continue their adventure in the future taking part in similar training. An important role in this area was played by questions related to the assessment of acquired digital skills and their possible use in private or professional life. The distribution of answers to questions regarding the assessment of the suitability of training is presented below (Fig. 4).

The respondents also evaluated the entire training. They focused primarily on properly selected topics, substantive connections of the issues discussed, the proportion of time devoted to particular topics and the selection of training topics. The distribution of responses to questions asked in the survey are presented below (Fig. 5). 


$$
\begin{aligned}
& \text { participant plans to participate in similar } \\
& \text { training in the future } \\
& \text { participant will recommend training to } \\
& \text { other people }
\end{aligned}
$$

after the training, the participant has new ideas that can be used in professional work and everyday life

the skills acquired will be useful at work/ /in private life

the training extended their skills

the training fulfilled the participant's expectations

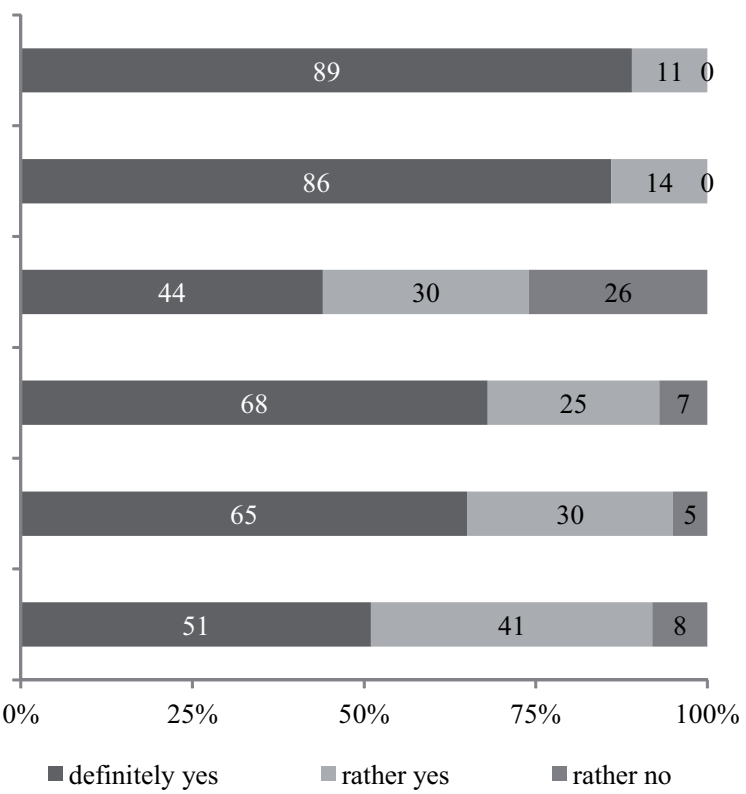

FIG. 4. The distribution of answers to questions regarding the suitability of training [\%]

Source: the author's research.

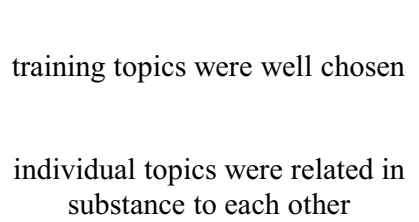

the time spent on each topic was right

the selection of topics corresponded to the participant's needs

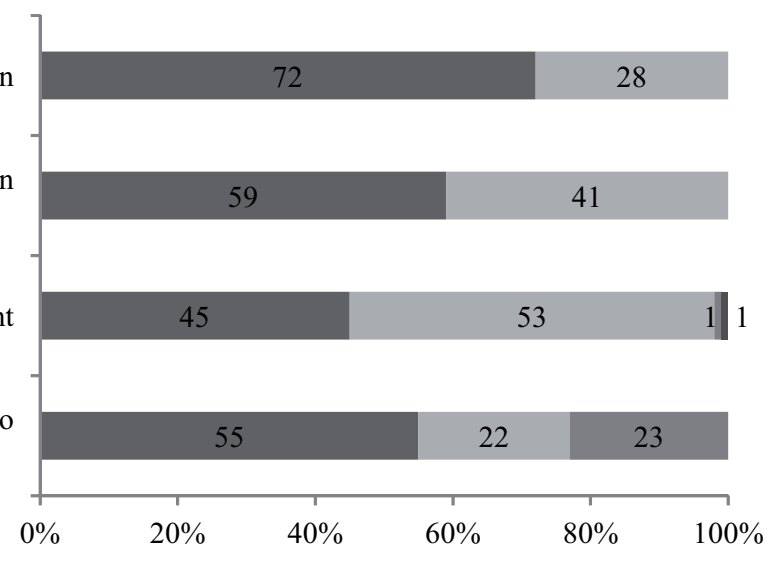

definitely yes $\quad$ rather yes $\quad$ definitely no $\quad$ rather no

FIG. 5. The distribution of answers to questions regarding the overall evaluation of the entire training $[\%]$

Source: the author's research. 
The curriculum for acquiring skills in the field of broadly understood information and communication technologies was each time matched to the individual needs of people participating in the training. In spite of this, among the topics that the respondents thought were the most desirable were: computer skills, Internet skills, including the use of electronic mail and the ability to use word processors. It should be emphasized that these are skills that are currently considered as basic skills.

\section{CONCLUSIONS}

Digital competences are among the eight competences mentioned by the European Parliament and the Council of the European Union as key and necessary skills for the implementation of the lifelong learning process. Their absence causes certain deficits and affects the exposure of a group of people to digital exclusion. Elderly people and people living in rural areas are among the most vulnerable to digital exclusion. In the case of the above-mentioned groups, digital exclusion is associated with the lack or low level of skills related to ICT.

The number of people with Internet access in the European Union is growing every year. In 2014, the highest percentage of households with Internet access was recorded in Luxembourg and the Netherlands, and the lowest in Bulgaria. The various surveys carried out over several decades show that the percentage of Poles who use modern information and communication technologies is increasing from year to year. However, it should be noted that the impact on the percentage of people using the Internet depends on the level of education, place of residence, age or wealth. Older, less educated, poorer and rural people are the most vulnerable to digital exclusion. Modern information and communication technologies serve their users both in professional and everyday life. The interest and use of this technology are growing year by year, as evidenced by the dynamic development of e-commerce. As the research shows, also better-educated people living in smaller and larger cities and younger people benefit from shopping online. All this also affects digital exclusion and increases the disproportion between people who have access to the Internet and those who do not have such a possibility.

As part of the funds coming from the European Union, activities are carried out aimed at the development of digital competences among groups vulnerable to social exclusion and social capital development, which is based on activities aimed at strengthening these competences. One of such activities was the Digital Poland of Equal Opportunities project. The originators of this undertaking directed their activities towards people over 50 years of age. It was based on the work of lamplotters - volunteers who acted as a modern social animator. As part of the Digital Poland of Equal Opportunities project, several dozens of initiatives were implemented, two of them: "Lowiccy seniorzy XXI wieku" and "Księżacy on-line" implemented in the county of Łowicz. Both projects were directed to people aged 50+ from the Łowicki county and living in rural areas, ie to the group of people most exposed to digital exclusion. The idea that guided the projects was a response to the activities of individual EU institutions in the whole process of lifelong learning. 
During the course of the classes, research was conducted in which 100 participants took part, of which half were pensioners, then working people and the unemployed. Most of them were also people who had a computer with access to the Internet, but nevertheless, they did not have the proper skills to use it. Due to the fact that the group of people to whom the training was addressed was a less active group, the organization of training which were to encourage them to continue their education played an important role. In working with people over 50, the attitude of the person leading is important and affects the entire learning process. The activities that have been presented and characterized in this article undoubtedly contribute to the development of social capital by strengthening digital skills, especially among social groups vulnerable to exclusion. Activities implemented under two projects were the only of many tasks implemented in Poland, which contributed to reducing disparities between people who have access to a computer and the Internet, and people who do not have the opportunity to use modern communication and information technologies.

\section{REFERENCES}

BATORSKI D., 2015. Technologie i media w domach i w życiu Polaków (Technologies and media in homes and in the lives of Poles) [in Polish] (in:) J. Czapiński, T. Panek (eds), Diagnoza społeczna 2015, Warszawa, 373-395.

DACH Z., 2008. Rynek pracy w Polsce. Aspekty ekonomiczno-społeczne (Labour market in Poland. Economic and socialaspects) [in Polish], Wydawnictwo Uniwersytetu Ekonomicznego w Krakowie, Kraków.

EUROSTAT 2017, retrived from http://ec.europa.eu/eurostat [accesses: 01.02.2018].

GAREIS K., HÜSING T., BIROV S., BLUDOVA I., SCHULZ C., KORTE W.B. 2014. E-skills for jobs in Europe: measuring progress and movingahead, final report, Germany, retrived from http://eskills-monitor2013.eu/fileadmin/monitor2013/documents/monitor_final_report.pdf [accessed: 01.02.2018].

Gemius, E-commerce w Polsce 2015. Gemius dla e-Commerce Polska (E-commerce in Poland 2015. Gemius for e-Commerce Poland) [in Polish], retrived from www.gemius.pl/files/ reports/E-commerce-w-Polsce-2015.pdf [accessed: 01.02.2018].

Gemius, E-commerce w Polsce 2017. Gemius dla e-Commerce Polska (E-commerce in Poland 2017. Gemius for e-Commerce Poland) [in Polish], retrived from www.gemius.pl/wszystkie-artykuly-aktualnosci/najnowsze-dane-o-polskim-e-commerce-juz-dostepne.html [accessed: 01.02.2018].

GROCHAL-BREJDAK M. 2016. Charakterystyka rynku e-commerce w Polsce w kontekście internacjonalizacji przedsiębiorstw e-commerce (Characteristics of Polish E-commerce Market in the Context of Internationalization of E-commerce Enterprises) [in Polish], Marketing i rynek 8, 19-24.

GÓRNIAK J. (ed.) 2014. Kompetencje Polaków a potrzeby polskiej gospodarki (Competences of Poles and the needs of the Polish economy) [in Polish], PARP, Warszawa.

Local Data Bank, Central Statistical Office, retrived from https://bdl.stat.gov.pl/BDL/start [accessed: 01.02.2018].

MANIAK G., 2015. Kształcenie przez całe życie - idea i realizacja. Polska na tle Unii Europejskiej (Lifelong learning - idea and implementation. Poland on the background of the European 
Union) [in Polish], Studia Ekonomiczne. Zeszyty Naukowe Uniwersytetu Ekonomicznego w Katowicach 214, 128-139.

MOCZYDŁOWSKA J.M., 2008. Zarządzanie kompetencjami zawodowymi a motywowanie pracowników (Management of professional competence and motivation of employees) [in Polish], Difin, Warszawa.

NOWAK A., 2012. Pojęcie, istota, przyczyny, mechanizmy marginalizacji i wykluczenia społecznego (Notion, essence, etiology and mechanismsof social marginalization and exclusion) [in Polish], Chowannar 1, 17-32.

POPIOŁEK M., 2013. Wykluczenie cyfrowe w Polsce (Digital divide in Poland) [in Polish]. Nierówności społeczne a wzrost gospodarczy 32, Wydawnictwo Uniwersytetu Rzeszowskiego, 310-321.

SZYMAŃSKA-PALACZYK A., 2016. Wolontariat w Polsce. Przykład projektu Polska Cyfrowa Równych Szans (Volunteeringin Poland: The Digital Poland of Equal Opportunities Project (PCRS)) [in Polish], Ruch Prawniczy, Ekonomiczny i Socjologiczny 78, 1, 255-271.

TOMASZEWSKA A., 2013. Dostęp do technologii informacyjno-komunikacyjnych w społeczeństwie informacyjnym. Przykład polskich regionów (The access to information and communications technologies in the informationsociety. The example of Polish regions) [in Polish], Acta Universitatis Lodziensis Folia Oeconomica 290, 23-37.

Warszawski Instytut Studiów Ekonomicznych i Centrum Cyfrowe, 2015. Projekt: Polska, Analiza doświadczeń oraz identyfikacja dobrych praktyk w obszarze wspierania rozwoju kompetencji cyfrowych w kontekście przygotowania szczegółowych zasad wdrażania Programu Operacyjnego Polska Cyfrowa na lata 2014-2020 oraz koordynacji celu tematycznego 2 (Project: Poland, Analysis of experiences and identification of goodpractices in the area of supporting the development of digitalcompetences in the context of preparation of detailedrules for the implementation of the Operational Program Digital Poland for 2014-2020 and coordination of the thematic objective 2) [in Polish], Warszawa.

WWW 1. Retrived from www.latarnicy.pl [accessed: 01.02.2018].

Zalecenie Parlamentu Europejskiego i Rady z dnia 18 grudnia 2006 roku w sprawie kompetencji kluczowych w procesie uczenia się przez całe życie (2006/962/WE) (Council Recommendationon Key Competencesfor Lifelong Learning 2006/962/EC) [in Polish].

Summary. Competitive advantage in the professional market is shaped by the competences possessed, i.e. skills, qualifications, and permissions. One of the eight types of key competences mentioned in the European Union documents is digital competence.It is a collection of knowledge, skills, and rudiments necessary for both, the purposeful point of view and active participation of a given person in social life. The low level of digital competences possessed is particularly visible among groups at risk of digital exclusion, in particular among people living in rural areas, the elderly and people with low education. The difference between people who have access to a computer and the Internet and people who do not have the possibility to use these devices is affected by the dynamic development of information and communication technologies. Digital exclusion is not only the lack of access to the appropriate infrastructure but also the lack of computer and Internet skills. In order to counteract the exclusion of these groups, activities aimed at developing social capital by strengthening digital competences play an important role. 
Key words: social capital, key competences, digital competences, digital exclusion, Łowicki county

JEL: D83, E24, I24, I25

Corresponding author: Paweł Pięta, Warsaw University of Life Sciences - SGGW, ul. Nowoursynowska 166,02-787 Warszawa, Poland, e-mail: pawelpieta@o2.pl.

Received: $\quad 03.02 .2018$

Accepted: 15.04 .2018 